\title{
Increasing Fat Deposition via Upregulates the Transcription of Peroxisome Proliferator-Activated Receptor Gamma (PPARY) in Native Crossbred Chicken
}

\author{
Supanon Tunim \\ Khon Kaen University \\ Yupin Phasuk \\ Khon Kaen University \\ Samuel E. Aggrey \\ University of Georgia \\ Monchai Duangjinda ( $\nabla$ monchai@kku.ac.th ) \\ Khon Kaen Universtiy https://orcid.org/0000-0001-7044-8271
}

\section{Research article}

Keywords: Thai native crossbred chickens, PPAR, Gene expressions, Fat deposition

Posted Date: July 16th, 2020

DOI: https://doi.org/10.21203/rs.3.rs-32691/v1

License: (9) This work is licensed under a Creative Commons Attribution 4.0 International License. Read Full License

Version of Record: A version of this preprint was published at Animals on January 5th, 2021. See the published version at https://doi.org/10.3390/ani11010090. 


\section{Abstract}

Background: Crossbreeding using exotic breeds is usually employed to improve the growth characteristics of indigenous chickens. This mating not only provides growth but affect adversely to fat deposition as well. We studied the growth, abdominal, subcutaneous and intramuscular fat and mRNA expression of peroxisome proliferator-activated receptor (PPAR) $a$ and PPARy in adipose and muscle tissues of four chicken breeds [Chee breed (CH) (100\% Thai native chicken), Kaimook e-san1 (KM1; 50\% $\mathrm{CH}$ background), Kaimook e-san2 (KM2; 25\% CH background), and broiler (BR)]. This study was aim to study role of PPARs on fat deposition in native crossbred chicken.

Results: The BR chickens had higher abdominal fat than other breeds $(P<0.05)$ and the KM2 had an abdominal fat percentage higher than $\mathrm{KM} 1$ and $\mathrm{CH}$ respectively $(\mathrm{P}<0.05)$. The intramuscular fat (IMF) of $\mathrm{BR}$ was greater than $\mathrm{KM} 1$ and $\mathrm{CH}(\mathrm{P}<0.05)$. In adipose tissue, PPARa transcription expression was different among the chicken breeds. However, there were breed differences in PPARy gene expression. Study of abdominal fat PPARy gene expression showed the BR breed, KM1, and KM2 breed significantly greater $(\mathrm{P}<0.05)$ than $\mathrm{CH}$. In 8 to 12 weeks of age, the result shows that the PPARy expression of the $\mathrm{CH}$ breed is less than $(P<0.05) \mathrm{KM} 2$. The result of PPARs expression in muscle tissue was similar result in adipose tissue.

Conclusion: Crossbreeding improved the growth of the Thai native breed, there was also a corresponding increase in carcass fatness. However, there appears to be a relationship between PPARY expression and fat deposition traits. therefore, PPARY activity plays a key role in lipid accumulation by up-regulation.

\section{Background}

In tropical climate countries, native chickens which evolved from jungle fowl are distributed widely. In Asian countries, they are numerous slow-growing and lean breeds [1]. These indigenous poultry strains generally have low fat and ability to tolerate the effect of heat stress. On the other hand, commercial broilers are selected for rapid growth and do not express their full genetic potential under hot-humid climates.

In tropical regions, crossbreeding of indigenous breeds with improved exotic breeds has been one of the strategies to improve growth of the indigenous breeds. Crossbreeding has been used in many countries including Nigeria, Thailand, Bangladesh and India to improve growth and egg production [2]. High producing exotic commercial broiler strains have high growth performance and significant amount of visceral fat compared to the indigenous breeds. Crossbreeding can also increase fat deposition in both intramuscular fat and subsequently affect meat flavor [3]. Excessive carcass fatness can also have a negative effect on dressing percentage of chicken and consumer health due to high-fat content of the meat.

It is important to understand the lipogenesis mechanism in poultry crossbred in order to ascertain the optimal level of infusion of exotic (genes) allele into indigenous breeds to take advantage of the growth 
potential and simultaneously limiting visceral fat. The metabolism of avian species is complex and may have a different mechanism from mammalian species [4, 5]. Lipogenesis is mediated in part by fatty acid binding proteins (FABPs), lipoprotein lipase (LPL) and fatty acid synthase (FAS), and the transcriptional expression of nuclear receptors [6].

The peroxisome proliferator-activated receptors (PPARs) are a superfamily of nuclear receptors which play a significant role in adipocyte cell differentiation and intra and extracellular transportation of fatty acid $[5,7]$. PPARy is one of the most important subtypes, which has activity in oil droplet accumulation by regulated glucose and fatty acid uptake and directly combines with PPAR response element (PPRE) [8]. Contrary to PPARy, PPARa serves in lipid catabolism, especially $\beta$-oxidation via upregulating related enzymes [9].

The objective of the current study was to investigate the mRNA expression of nuclear receptors, PPARa and PPARy in chicken adipose and intramuscular fat tissues in Thai native chickens with different percentages of commercial broiler genotypes.

\section{Results}

\section{Carcass fat deposition among various genetic background of chickens}

The fat deposition in the abdominal, subcutaneous tissue, skin, P. major and thigh muscle were investigated in different breeds (Figure 1). The $\mathrm{CH}$ breed had the lowest fat deposition $(P<0.05)$ compared with $\mathrm{KM} 1, \mathrm{KM} 1$ and BR for all the tissues studied. At week 6 , the BR breed had significantly higher fat percentage in all tissues except skin fat compared to the other breeds. From 8 to 12 weeks, there comparison was between $\mathrm{CH}, \mathrm{KM} 1$ and $\mathrm{KM} 2$. The $\mathrm{KM} 2$ breed had the highest percentage $(\mathrm{P}<0.05)$ of abdominal fat compared to $\mathrm{KM} 1$ and $\mathrm{CH}$ ). Skin percentage and skin fat in both $\mathrm{KM} 1$ and $\mathrm{KM} 2$, were not different $(\mathrm{P}>0.05)$. There is a significantly higher intramuscular fat (IMF) of $\mathrm{BR}$ in both $P$. major and $B$. femoris than $\mathrm{KM} 1$ and $\mathrm{CH}(\mathrm{P}<0.05)$ but not different with $\mathrm{KM} 2$. From 8 to 12 weeks, $\mathrm{CH}$ breed was lower IMF than KM2 in both muscle tissues $(P<0.05)$. While there was no difference in intramuscular fat between $\mathrm{KM} 1$ and $\mathrm{KM} 2$ chickens.

\section{Differentiation of PPARa mRNA expression in various breed of chickens}

Transcriptional levels of PPARa in abdominal fat and breast muscular tissue are demonstrated in Figure 2 (a) and 3 (a) respectively. In this current study, we found a significant difference in PPARa expression between $\mathrm{BR}$ and $\mathrm{CH}(\mathrm{P}<0.05)$ at 6 weeks of age. While no difference could be found among expression by KM1, KM2 and BR. At 8 weeks of age, $\mathrm{CH}$ breed expressed PPARa mRNA levels less than $(P<0.05) \mathrm{KM} 1$ 
breed which was not different between the expression of both crossbred chickens. However, during 10 to 12 weeks of age, there are no differences in PPARa expression between breeds in abdominal fat tissue. There was no difference in muscular PPARa expression levels among studied breeds throughout the study.

\section{Differentiation of PPARY mRNA expression in various breed of chickens}

Abdominal fat and breast muscular tissue were investigated for PPARy gene expression level for breed comparison as shown in Figures 2 (b) and 3 (b). Abdominal fat PPARy gene expression in BR, KM1 and KM2 breeds had higher mRNA expression levels $(\mathrm{P}<0.05)$ than $\mathrm{CH}$ breed but not found different expression level among BR, KM1, and KM2 at 6 weeks of age. At 8th weeks of age, $\mathrm{CH}$ and $\mathrm{KM} 1 \mathrm{had}$ similar mRNA expression but both had lower PPAR $y$ expression $(P<0.05)$ when compared with KM2. At 12 weeks of chicken age, the results show that the PPARy expression of the $\mathrm{CH}$ breed was less than $(\mathrm{P}<0.05)$ both crossbred breeds of chicken.

In the P. major, PPARy expression was higher $(\mathrm{P}<0.05)$ in BR compared to the other breeds at 6 weeks of age, however, there were no differences among $\mathrm{CH}, \mathrm{KM} 1$ and KM2. At 8 and 10 weeks of age, PPARY expression was higher in $\mathrm{KM} 2$ compared to $\mathrm{KM} 1$ and $\mathrm{CH}$ and the differences between $\mathrm{CH}$ was not significant.

\section{Correlation between PPARs expression and fat deposition in slaughtering trait}

Pearson correlation coefficient was calculated from all breeds 6 to 12 weeks of age for PPAR expressions and fat deposition traits (Table 2). PPARy transcriptional level in abdominal fat tissue showed a positive correlation with adipose tissue accumulation in the abdomen and in skin structure $\left(r_{p}=0.33-0.38\right)$. PPARa inversely correlated with skin fat at -0.26 . Intramuscular fat in both breast and thigh tissues had moderate positive correlation with PPARy expression (0.34-0.43). On the other hand, PPARa had no correlation with fat depositions in both adipose and muscular tissues. There was a positive correlation between muscular PPARy expression and adipose tissue fat accumulation which were $0.37,0.26$ and 0.20 for abdominal, subcutaneous and skin fat respectively.

\section{Discussion}

\section{Impact of crossbreeding of Thai native chickens on growth}

Indigenous chickens are important in developing countries for food security, and the socio-cultural life of the rural community [2]. The Thai native chickens are important genetic resource, as they are adapted to 
the harsh environmental conditions and have chewy texture and taste that are preferred by consumers in Thailand [1]. Despite these advantages, the growth performance of the native chickens is poor and as a result, crossbreeding with fast growing exotic strains have been encouraged to improve the growth characteristics of the native breeds. In the current study, the KM1 and KM2 crossbred chickens with 50 and $25 \%$, respectively of native Thai chicken background showed significant improvement in growth. The KM1 and KM2 chickens grew about 1.3 and 2.3 folds, respectively when compared with the $\mathrm{CH}$ breed.

The improvement in growth of the native Thai breed has come with associated increased in body fatness. Abdominal fat, which is an excessive fat and considered as waste in the slaughtering process. This is a clear positive relationship between growth performance and abdominal fat accumulation. The fat deposition has been correlated with adipocyte enlargement [10]. Improvement in growth and accumulation of fatness associated with crossing breeding of indigenous chickens with exotic breeds have been documented in several other native crossbreeding programs [11]. This has been shown to be due to the pleiotropic effect between body weight and abdominal fat traits [12]. With the faster growth rate of the KM2 chickens because of the higher percentage of exotic genes, it is expected that they will reach slaughter age much faster than the $\mathrm{KM} 1$ crossbred and the $\mathrm{CH}$ breed.

Contrarily to expectation, the KM1 and KM2 did not show any differences in subcutaneous and skin fat, but they both had values higher than the $\mathrm{CH}$ breed. It has been documented that, the weight of the skin is dependent on the amount of subcutaneous fat deposition [12]. However, from the current study, there phenotypic correlation between skin and subcutaneous fats was 0.54 . There may be other non-genetic factors contributing towards the relationship between subcutaneous fat and skin fat.

The intramuscular fat (IMF) represents the lipid that is distributed in muscular tissue containing epimysium, perimysium, and endomysium which infiltrates between the muscular fiber bundles. IMF has an influence on meat quality which vary depending on sex, slaughter age and type of muscle [13]. The $\mathrm{CH}$ breed has relatively low IMF accumulation in both breast and leg muscle while BR and KM2 have significantly high amount of IMF. The current report suggests that crossbreeding of the Thai native chickens with exotic breeds have the potential to change not only the growth performance but the meat quality as well.

Zhou et al. [14] demonstrated that the meat from selected for increased fat content have lower in shear force than their control counterparts. Potentially, the meat of the KM1 and KM2 may be more tender than the native $\mathrm{CH}$ breed due to their relatively high IMF. However, [15] did not observe any differences in IMF between native Thai and Barred Plymouth Rock crossbred and the native chickens when breast and thigh muscles were compared. Similarly, crossbreeding Chinese native chickens did not affect breast IMF [11].

\section{PPARs transcription factors regulating cellular lipid metabolism}


In chickens, endogenous lipids are mainly synthesized as lipoprotein in the liver from dietary glucose and then export to extrahepatic tissues by circulation in the blood stream, where the lipoproteins are hydrolyzed by lipoprotein lipase and fatty acids are released for use as energy or accumulation in the cell $[13,16]$. At the cellular level, The many types of functional proteins related to lipid metabolism were reviewed in [17] that included Fatty Acid Binding Proteins (FABPs), insulin-dependent glucose transporter 4 (GLUT4), lipoprotein lipase (LPL) and the fatty acid translocase (CD36), which were stimulated by transcription factor PPAR. PPARs are important cellular regulators which respond to energy status during both fed and fasted states [18]. The PPARs function and mechanism in mammalian species were studied, while many studies focused on the differences in lipid metabolism at the molecular level between avian and other species, and the unique PPARs function in chicken lipid metabolism [19].

PPARa is one of the transcription factors involved in the regulation of the ketogenesis pathway [18]. Palmitolyation forges the PPARa Mitochondrial 3-hydroxy-3-methylglutaryl-CoA synthase (HMGCS2) interaction which is a nodal point in the ketogenic mechanism, and this complex is transported to the nucleus where it activates PPRE to encode the transcription of HMGCS gene for autoregulation of its own nuclear transcription [20].

At 6 weeks of age, PPARa mRNA expression in adipose tissue was significantly downregulated in the commercial breed of chicken (BR) compared to $\mathrm{CH}$ and KM1. The downregulation may be the effect of cellular energy conservation of Brand KM2 and lead to the remaining fat to enlargement of abdominal fat tissue. From the current study, it appears that mRNA expression of PPARa is not directly dependent on the genetic background due to there was in the stage that unnecessary to use visceral fat as energy sources. In the current study, PPARa transcriptional level in muscle (Figure 3) did not differ among the breeds studied. This may be due to the muscle type as breast muscle require low energy because of lack of movement. We did not observe any significant phenotypic correlation between PPARa mRNA expression level and IMF in both breast and thigh tissues. Thus, the increase in IMF with the muscles of the Thai native crossbreds was not due to changes in PPARa transcription. On the contrary, [21] reported a positive relationship between PPARa expression and IMF deposition in dwarf chicken which has deletion mutation in $3^{\prime} U T R$ of GHR leading to a reduction of body weight and increased IMF accumulation.

However, there appears to be a relationship between PPARy expression and IMF. The PPARY mRNA expression of BR and crossbred chicken (KM1 and KM2) were in concordance with the fat deposition traits. PPARY is one of the most important subtypes, which has activity in oil droplet accumulation within adipose tissue. However there are many related mechanisms such as glucose and fatty acid uptake regulation by $L P L, G L U T$, and A-FABP $[8,22]$. Therefore, these lipid accumulations of $B R, K M 1$ and KM2 could occur putatively via cellular uptake and transport fatty acid for storage as triglyceride. Moreover, the coefficient correlation revealed that PPARy expression has a moderate positive correlation with abdominal and skin fat. Moreover, Wang et al. [23] showed that the A-FABP gene is down-regulated when PPARy is silenced, therefore, PPARy activity plays a crucial role in cellular lipid accumulation by A-FABP activity especially in lipogenesis and may has potential as target gene for selection against excessive fat deposition in chickens. We have shown that A-FABP is upregulated in concordance with the fatness level 
of the breed [24]. The phenotypic correlation between PPARY mRNA expression and IMF for both breast and thigh muscles was positive. This is corroborated by other studies using the Chinese native chickens and female Wuhau chickens [25].

\section{Conclusion}

We studied the relationship between abdominal, subcutaneous and intramuscular fat in Thai native crossbreds, an exotic commercial broiler and the Thai native breed, Chee. Crossbreeding significantly improved growth with a concordance increase in carcass fatness. There are appears to be no relationship between fatness and mRNA expression of PPARa. However, the transcriptional expression level of PPARY in both adipose and muscular tissue seems to correlate with the amount of fatness in the breed studied. It is thought that inclusion of exotic genes in the Thai native chickens may also affect the meat quality, even though carcass fatness may also increase.

\section{Methods}

\section{Birds and rearing condition}

This study was approved by Institute of Animal for Scientific Purpose Development (IAD, IACUC-KKU34/62). We received healthy purebred and crossbred Thai native chickens in stage of day-old chicks (about 29.5-36.9 gram of body weight) from Research and Development Network Center for Animal Breeding of Khon Kaen university. The Arbor Acre commercial broiler used in this study was purchased at stage of day-old chicks (about 42.3 gram of body weight) from Charoen Pokphand Group Company Limited. The study was conducted with four genotypes. The native Thai breed, Chee $(\mathrm{CH})(100 \%$ Thai native chicken background: $0 \%$ broiler background), $\mathrm{CH}$ male and broiler female (Kaimook e-san1; KM1) (50\% Thai native chicken background: $50 \%$ broiler background), broiler male and KM1 female (Kaimook e-san2; KM2) (25\% Thai native chicken background: $75 \%$ broiler background), and broiler (BR) (0\% Thai native chicken background: $100 \%$ broiler background). Chickens were raised under the same management and husbandry conditions and fed with commercial broiler diet throughout the experiment. The poultry house was an open-air system. There were four pens per genotype, and 25 birds per pen. All chickens were fed ad-libitum on a diet consisting of $21 \%$ crude protein (CP), $3100 \mathrm{kcal}$ of ME/ $\mathrm{kg}$ for starter diet and $19 \% \mathrm{CP}$ and $3200 \mathrm{kcal}$ of $\mathrm{ME} / \mathrm{kg}$ for growing diet.

\section{Slaughtering, fat deposition data and tissue collection}

Twenty birds (10 males and 10 females) were randomly selected per genotype at 6, 8, 10 and 12 weeks of age for slaughter by rapidly cervical dislocation (not more than 5 second) in slaughter house before jugular vein bleeding according to an approved protocol (IAD, IACUC-KKU-34/62) except the commercial broiler which was selected and slaughtered only at 6 weeks of age. 
After the slaughtering process, blood and feathers were discarded from the carcass. Abdominal fat, including around the gizzard and proventriculus, was immediately collected and weighed. Whole-body skin with subcutaneous fat, except in wingtip were carefully isolated and weighed and designated as abdominal- and subcutaneous fat percentage expressed as a percentage of carcass weight. Sliced right breast (Pectoralis major),, right thigh (Bicep femoris) and skin (whole breast skin) of chickens ( $\mathrm{n}=8 / \mathrm{per}$ week per breed) were collected into a vacuum bag and stored at $-20{ }^{\circ} \mathrm{C}$ until further analysis. The samples were extracted in triplicates with petroleum ether for the fat percentage. Samples of $P$. majorand abdominal fat $(n=8)$ per week per genotype were taken from the central portion of these tissues into an insulated bag and snap-frozen by liquid nitrogen and stored at $-20^{\circ} \mathrm{C}$ freezer until used in RNA extraction.

\section{Quantitative reverse transcription polymerase chain reaction (qRT-PCR)}

Total RNA was extracted from randomized parts of tissue within P. major and abdominal fat tissues using GeneJET RNA Purification Kit (Thermo Scientific, USA). Concentrated and purified RNA yield was then quantified by The NanoDrop ${ }^{\mathrm{TM}}$ 2000/2000c Spectrophotometer (Thermo Scientific, USA). Ratios of absorption $(260 / 280 \mathrm{~nm})$ of all extracted RNA was in range between 1.8-2.0. Qualified RNA products were storage at $-20^{\circ} \mathrm{C}$ until using in further analysis.

Bio-Rad CFX96 Touch Real-Time PCR Systems (Bio-Rad, USA), with optical grade plates using IQTM PCR plate (Bio-Rad, USA) was used in quantitative reverse transcription polymerase chain reaction (qRT-PCR) analyses. We analyzed the RNA expression of PPARa and PPARy using 18s rRNA as a reference gene for normalization. Sequencing, fragment size, and annealing temperature of the primers are presented in Table 1. Primers were purchased from 1st BASE Oligonucleotide Synthesis (1st Base, Singapore). The single step RT-PCR was used to investigate target gene expression by the SensiFAST ${ }^{\mathrm{TM}}$ SYBR ${ }^{\circledR}$ No-ROX One-Step Kit (Bioline, Memphis, USA). Each sample was amplified in duplicate. Each bird was used as experimental unit which used the $2^{-\triangle \Delta \mathrm{Ct}}$ method to assess the fold change [26] using the $\mathrm{CH}$ genotype as the control.

\section{Statistical analysis}

All data including fat deposition and the gene expression were evaluated assumption of ANOVA by PROC univariate procedure before analyzed by ANOVA using the Generalized Linear Model (GLM) procedure by SAS statistical software package, version 9.0 (SAS Institute, Inc., Cary, NC, USA), and the means separated by Tukey. The phenotypic correlation was calculated between gene expression and fat deposition traits using Pearson correlation.

\section{Abbreviations}


PPAR: Peroxisome proliferator-activated receptor; PPARa: Peroxisome proliferator-activated receptor alpha; Peroxisome proliferator-activated receptory: Peroxisome proliferator-activated receptor gamma; $\mathrm{CH}$ : Chee breed of chickens; KM1: Kaimook e-san 1 breed of chickens; KM2; Kaimook e-san 2 breed of chickens; BR: Broiler chickens; IMF: intramuscular fat; A-FABP: Adipocyte fatty acid binding protein; LPL: lipoprotein lipase; FAS: fatty acid synthase; PPRE: PPAR response element; P.Major: Pectoralis major; B.femoris: Bicep femoris; mRNA: messenger ribonucleic acid; GLUT4: glucose transporter 4; CD36: fatty acid translocase; HMGCS2: hydroxy-3-methylglutaryl-CoA synthase; 3'UTR: 3' untranslated region; GHR: Growth hormone receptor; $\mathrm{CP}$ : crude protein; ME: Metabolizable energy; kg: kilogram; kcal: kilocalrolie; qRT-PCR: quantitative reverse transcription polymerase chain reaction; PCR: polymerase chain reaction; ANOVA: analysis of variance; GLM: Generalized Linear Model; SAS: statistical analysis software.

\section{Declarations}

\section{Acknowledgements}

We wish to thank our lab members for their helpful discussions and especially thank Marie C. Milfort for the revised and suggestion.

\section{Funding}

This study was financially supported by the Research and Researcher for Industry of the Thailand Research Fund (TRF) (Grant no. PHD58I0082). Studied material including farm and tool was supported by Research and development network center for animal breeding (native chicken), Faculty of agriculture, Khon Kaen University (KKU). The funders had no influence on the design, data collection, analysis, interpretation, decision to publish nor presentation of the data and results of this study.

\section{Availability of data and materials}

All the data supporting the conclusions of the study are included in the manuscript and Additional file 1. Analyzed methods are available from the corresponding author on reasonable request.

\section{Authors' contributions}

ST wrote the original draft, all authors reviewed and edited the final draft, SEA was responsible for the final draft, MD, YP and ST design the study and concept, SEA critical revision and directed the research. All authors read and approved the manuscript

\section{Competing Interests}


We certify that there is no conflict of interest with any financial organization regarding the material discussed in the manuscript.

\section{Consent for publication}

Not applicable

\section{Ethics approval and consent to participate}

All animal procedures were approved by the Khon Kaen University Institutional Animal Care and Use Committee under protocols (IAD, IACUC-KKU-34/62).

\section{References}

1. Jaturasitha S, Chaiwang N, Kreuzer M. Thai native chicken meat: an option to meet the demands for specific meat quality by certain groups of consumers; a review. Anim Prod Sci. 2017;57:1582.

2. Padhi MK. Importance of Indigenous Breeds of Chicken for Rural Economy and Their Improvements for Higher Production Performance. Scientifica. 2016;2016:1-9.

3. Cui H, Zheng M, Zhao G, Liu R, Wen J. Identification of differentially expressed genes and pathways for intramuscular fat metabolism between breast and thigh tissues of chickens. BMC Genomics. 2018;19:55.

4. Meng H, Li H, Zhao JG, Gu ZL. Differential expression of peroxisome proliferator-activated receptors alpha and gamma gene in various chicken tissues. Domestic Animal Endocrinology. 2005;28:10510.

5. Spiegelman BM. Peroxisome proliferator-activated receptor gamma: A key regulator of adipogenesis and systemic insulin sensitivity. Eur J Med Res. 1997;2:457-64.

6. Wang H-B, Li H, Wang Q-G, Zhang X-Y, Wang S-Z, Wang Y-X, et al. Profiling of chicken adipose tissue gene expression by genome array. BMC Genomics. 2007;8:193.

7. Royan M, Navidshad B. Peroxisome proliferator-activated receptor gamma (PPARY), a key regulatory gene of lipid metabolism in chicken. World's Poultry Science Journal. 2016;72:773-84.

8. Sato K, Abe H, Kono T, Yamazaki M, Nakashima K, Kamada T, et al. Changes in peroxisome proliferator-activated receptor gamma gene expression of chicken abdominal adipose tissue with different age, sex and genotype. Animal Science Journal. 2009;80:322-7.

9. Dreyer C, Keller H, Mahfoudi A, Laudet V, Krey G, Wahli W. Positive regulation of the peroxisomal $\beta$ oxidation pathway by fatty acids through activation of peroxisome proliferator-activated receptors (PPAR). Biology of the Cell. 1993;77:67-76.

10. Ramiah SK, Meng GY, Sheau Wei T, Swee Keong Y, Ebrahimi M. Dietary Conjugated Linoleic Acid Supplementation Leads to Downregulation of PPAR Transcription in Broiler Chickens and Reduction 
of Adipocyte Cellularity. PPAR Research. 2014. doi:10.1155/2014/137652.

11. Yin HD, Gilbert ER, Chen SY, Wang Y, Zhang ZC, Zhao XL, et al. Effect of Hybridization on Carcass Traits and Meat Quality of Erlang Mountainous Chickens. Asian-Australas J Anim Sci. 2013;26:1504-10.

12. Zerehdaran S, Vereijken ALJ, van Arendonk JAM, van der Waaijt EH. Estimation of genetic parameters for fat deposition and carcass traits in broilers. Poultry Science. 2004;83:521-5.

13. Hocquette JF, Gondret F, Baéza E, Médale F, Jurie C, Pethick DW. Intramuscular fat content in meatproducing animals: development, genetic and nutritional control, and identification of putative markers. animal. 2010;4:303-19.

14. Zhao GP, Chen JL, Zheng MQ, Wen J, Zhang Y. Correlated responses to selection for increased intramuscular fat in a Chinese quality chicken line. Poult Sci. 2007;86:2309-14.

15. Jaturasitha S, Kayan A, WICKE M. Carcass and meat characteristics of male chickens between Thai indigenous compared with improved layer breeds and their crossbred. Archiv fur Tierzucht. 2008;51.

16. Wang G, Kim WK, Cline MA, Gilbert ER. Factors affecting adipose tissue development in chickens: A review. Poult Sci. 2017;96:3687-99.

17. Hausman GJ, Dodson MV, Ajuwon K, Azain M, Barnes KM, Guan LL, et al. Board-invited review: the biology and regulation of preadipocytes and adipocytes in meat animals. J Anim Sci. 2009;87:121846.

18. Grabacka M, Pierzchalska M, Dean M, Reiss K. Regulation of Ketone Body Metabolism and the Role of PPARa. Int J Mol Sci. 2016;17.

19. Takada I, Kobayashi M. Structural Features and Transcriptional Activity of Chicken PPARs (, , and ). PPAR research. 2013;2013:186312.

20. Meertens LM, Miyata KS, Cechetto JD, Rachubinski RA, Capone JP. A mitochondrial ketogenic enzyme regulates its gene expression by association with the nuclear hormone receptor PPARalpha. EMBO J. 1998;17:6972-8.

21. Ye Y, Lin S, Mu H, Tang X, Ou Y, Chen J, et al. Analysis of Differentially Expressed Genes and Signaling Pathways Related to Intramuscular Fat Deposition in Skeletal Muscle of Sex-Linked Dwarf Chickens. BioMed Research International. 2014. doi:10.1155/2014/724274.

22. Matsubara $Y$, Sato $K$, Ishii $H$, Akiba $Y$. Changes in mRNA expression of regulatory factors involved in adipocyte differentiation during fatty acid induced adipogenesis in chicken. Comparative Biochemistry and Physiology Part A: Molecular \& Integrative Physiology. 2005;141:108-15.

23. Wang Y, Mu Y, Li H, Ding N, Wang Q, Wang Y, et al. Peroxisome Proliferator-Activated Receptor- $Y$ Gene: A Key Regulator of Adipocyte Differentiation in Chickens. Poult Sci. 2008;87:226-32.

24. Tunim S, Phasuk Y, Aggrey SE, Duangjinda M. Gene expression of fatty acid binding protein genes and its relationship with fat deposition of Thai native crossbreed chickens. Asian-Australasian Journal of Animal Sciences. 2020. in press. 
25. Chen X, Niu J, Geng Z. Gene expression and plasma lipid content in relation to intramuscular fat in Chinese indigenous Wuhua chicken. J Appl Poult Res. 2017;26:391-400.

26. Livak KJ, Schmittgen TD. Analysis of relative gene expression data using real-time quantitative PCR and the 2(-Delta Delta C(T)) Method. Methods. 2001;25:402-8.

27. Fenwick MA, Fitzpatrick R, Kenny DA, Diskin MG, Patton J, Murphy JJ, et al. Interrelationships between negative energy balance (NEB) and IGF regulation in liver of lactating dairy cows. Domestic Animal Endocrinology. 2008;34:31-44.

28. Meng H, Zhao JG, Li ZH, Li H. Single Nucleotide Polymorphisms on Peroxisome Proliferator-activated Receptor Genes Associated with Fatness Traits in Chicken. Asian-Australasian Journal of Animal Sciences. 2005;18:1221-5.

\section{Tables}

Table 1 Primer sequence, PCR product size and annealing temperature

\begin{tabular}{|c|c|c|c|c|}
\hline Genes & Sequences & Product (bp) & TM & Source \\
\hline \multirow[t]{2}{*}{ PPAR $\alpha$} & F: 5- AGGCCAAGTTGAAAGCAGA -3 & 217 & 58 & [10] \\
\hline & R: 5- GTCTTCTCTGCCATGCACAA-3 & & & \\
\hline \multirow[t]{2}{*}{ PPARY } & F: 5- GACCTTAATTGTCGCATCCAT - 3 & 237 & 56 & [10] \\
\hline & R: 5 - CGGGAAGGACTTTATGTATGA - 3 & & & \\
\hline \multirow[t]{2}{*}{ 18S rRNA } & F: 5- CGGCGACGACCCATTCGAAC- 3 & 99 & 62 & [27] \\
\hline & R: 5 - GAATCGAACCCTGATTCCCCGTC- 3 & & & \\
\hline
\end{tabular}

ble 2 Pearson correlation coefficient between PPARs mRNA expression and fat deposition traits in both adipose and muscle tissues

\begin{tabular}{|c|c|c|c|c|}
\hline \multirow[t]{2}{*}{ Fat deposition traits (\%) } & \multicolumn{2}{|c|}{ Adipose tissue } & \multicolumn{2}{|c|}{ Muscular tissue } \\
\hline & $\begin{array}{l}\text { PPAR } \alpha \\
(n=102)\end{array}$ & $\begin{array}{l}\text { PPAR } \gamma \\
(n=102)\end{array}$ & $\begin{array}{l}\text { PPAR } \alpha \\
(n=104)\end{array}$ & $\begin{array}{l}\text { PPAR } \gamma \\
(n=104)\end{array}$ \\
\hline Abdominal fat $(\mathrm{n}=258)$ & -0.02 & $0.38^{* *}$ & -0.02 & $0.37^{* *}$ \\
\hline Subcutaneous fat $(n=260)$ & -0.18 & 0.10 & 0.01 & $0.28^{* *}$ \\
\hline Skin fat $(n=104)$ & $-0.26^{*}$ & $0.32^{* *}$ & -0.06 & $0.20^{*}$ \\
\hline Breast intramuscular fat $(n=104)$ & $-0.23^{*}$ & $0.22 *$ & -0.04 & $0.39^{* *}$ \\
\hline Thigh intramuscular fat $(n=104)$ & $-0.28^{* *}$ & $0.36^{* *}$ & -0.04 & $0.46^{* *}$ \\
\hline
\end{tabular}

Figures 
(a) Abdominal fat

$\square$ CH $\square$ KM1 $\square \mathrm{KM} 2 \square \mathrm{BR}$

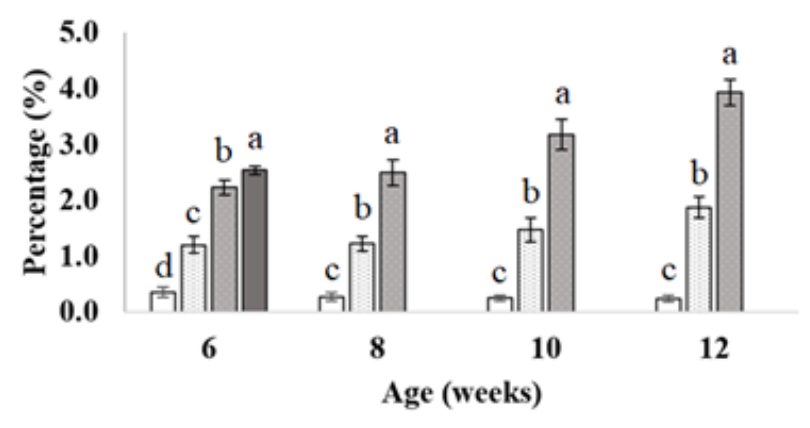

(b) Subcutaneous fat (Total skin)

$\square \mathrm{CH} \square \mathrm{KM} 1 \square \mathrm{KM} 2 \square \mathrm{BR}$

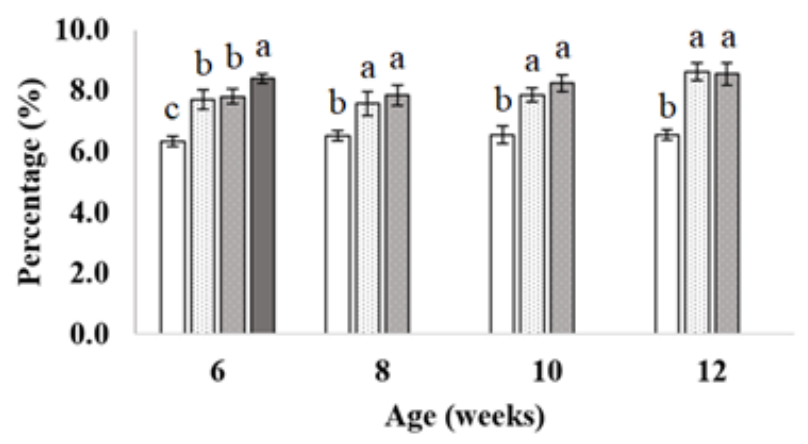

(d) Intramuscular fat (breast)

$\square \mathrm{CH} \square \mathrm{KM} 1 \square \mathrm{KM} 2 \square \mathrm{BR}$

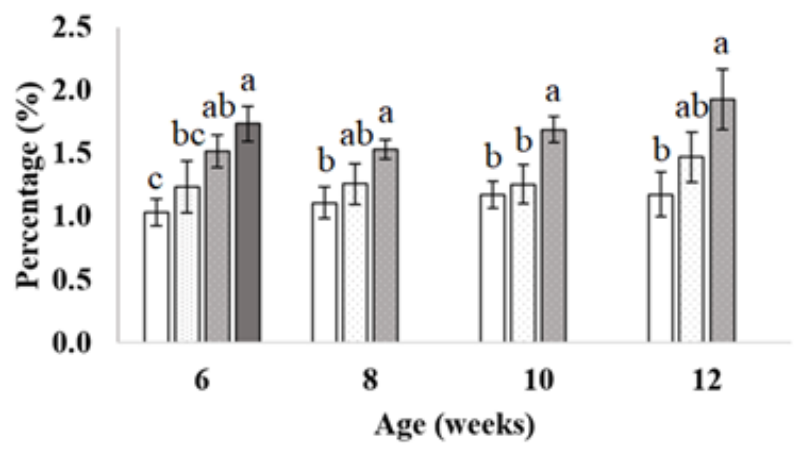

(c) Skin fat

$\square \mathrm{CH} \square \mathrm{KM} 1 \square \mathrm{KM} 2 \square \mathrm{BR}$

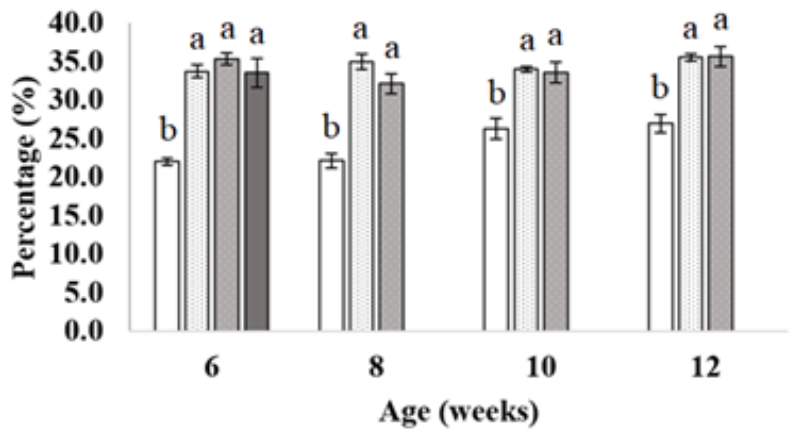

(e) Intramuscular fat (thigh)

$\square \mathrm{CH} \square \mathrm{KM} 1 \square \mathrm{KM} 2 \square \mathrm{BR}$

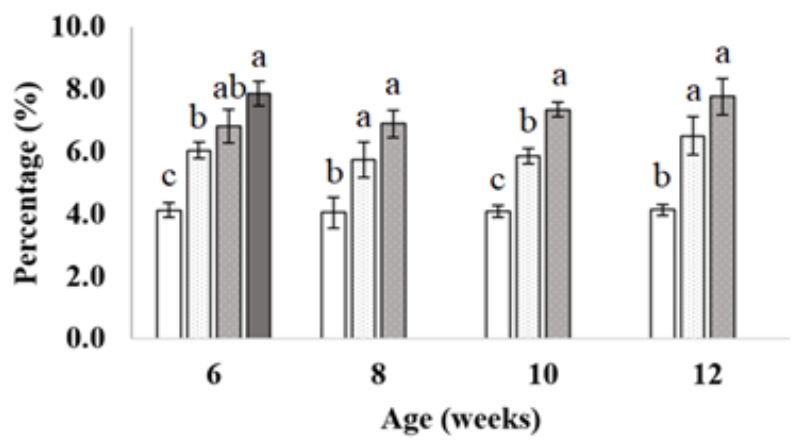

\section{Figure 1}

The fat deposition traits including abdominal fat (a), subcutaneous fat (b), skin fat (c), breast intramuscular fat (d) and thigh intramuscular fat (e) comparison between breeds of chicken in 6 - 12 weeks of slaughtering age. Noted: Abdominal, Subcutaneous and Breast intramuscular fat is partially based on our previous study [24]. $\mathrm{CH}=$ Chee breed, $\mathrm{KM} 1$ = Kaimook e-san1, KM2 = Kaimook e-san2, BR = Broiler chicken. $a, b$ Mean values within a figure with no common superscript differ significantly $(P<0.05)$ 
(a) PPAR $\alpha$ in adipose tissue

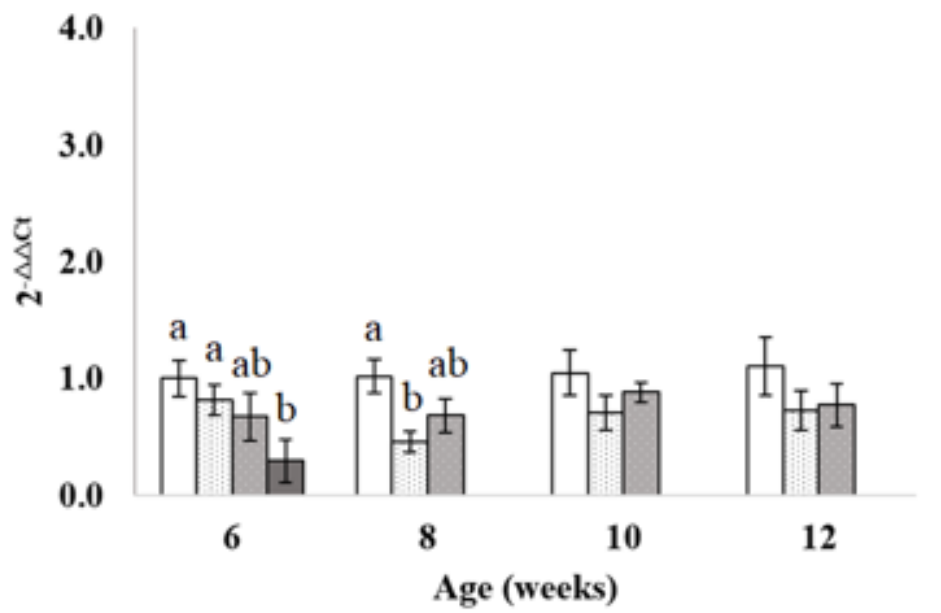

(b) PPAR $\gamma$ in adipose tissue

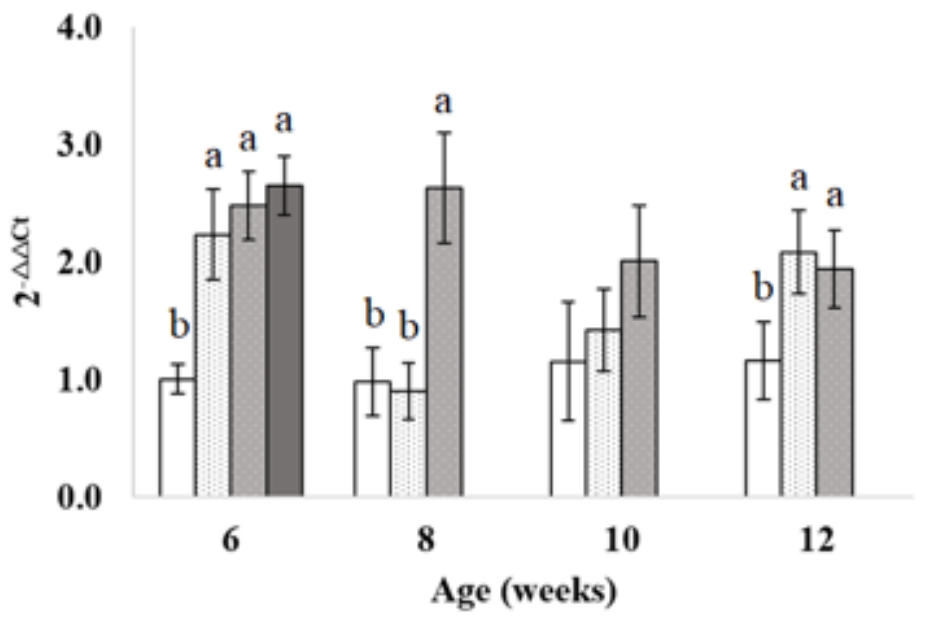

\section{$\square \mathrm{CH} \square \mathrm{KM} 1 \square \mathrm{KM} 2 \square \mathrm{BR}$}

\section{Figure 2}

Transcriptional expression level of PPARa (a) and PPARy (b) in abdominal fat tissue. $\mathrm{CH}=$ Chee breed, $\mathrm{KM} 1$ = Kaimook e-san1, KM2 = Kaimook e-san2, BR = Broiler chicken. $\mathrm{a}, \mathrm{b}$ Mean values within a column with no common superscript differ significantly $(P<0.05)$

(a) PPAR $\alpha$ in muscle tissue

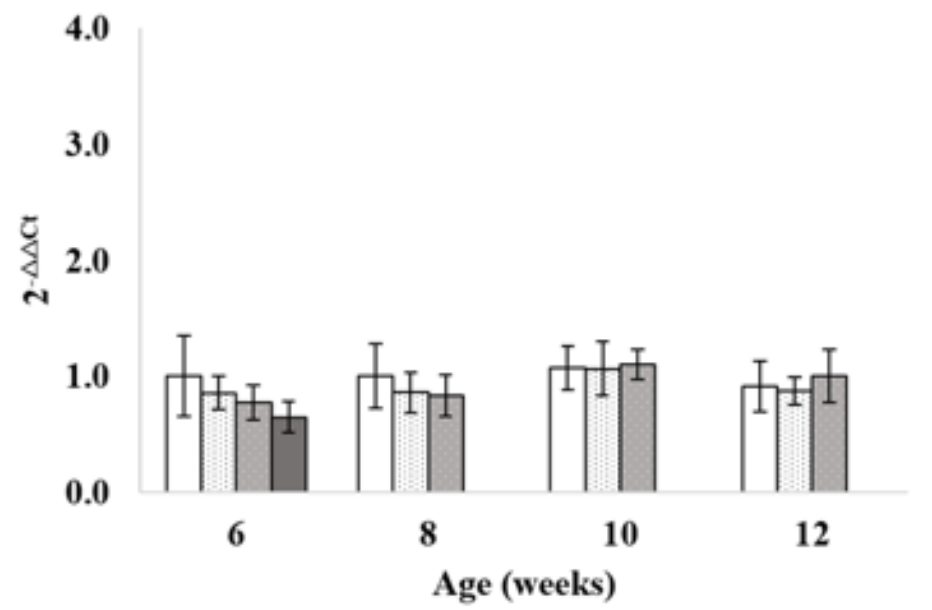

(b) PPAR $\gamma$ in muscle tissue

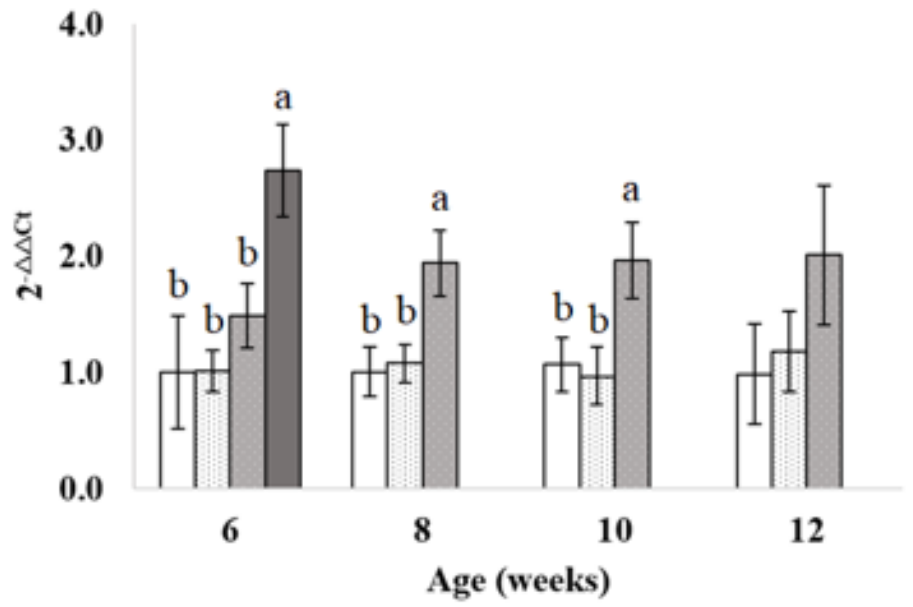

\section{$\square \mathrm{CH} \square \mathrm{KM} 1 \square \mathrm{KM} 2 \square \mathrm{BR}$}

\section{Figure 3}

Transcriptional expression level of PPARa (a) and PPARy (b) in breast muscle tissue. $\mathrm{CH}=$ Chee breed, $\mathrm{KM} 1$ = Kaimook e-san1, KM2 = Kaimook e-san2, BR = Broiler chicken. $a$, $b$ Mean values within a column with no common superscript differ significantly $(P<0.05)$ 


\section{Supplementary Files}

This is a list of supplementary files associated with this preprint. Click to download.

- TunimetalBMCadditionalfile.xlsx

- ChecklistTunimetal.pdf 